$\xi=-1$

\title{
Service Learning in Higher Education: Evidence from Malaysia
}

\author{
Norlaile Salleh Hudin ${ }^{1 *}$, Juliana Osman ${ }^{2}$, Suzyanty Mohd Shokory ${ }^{3}$, Hariyati Ab Wahid ${ }^{4}$ \\ ${ }^{1,2,3,4}$ Department of Business Management and Entrepreneurship, Universiti Pendidikan Sultan Idris, Malaysia \\ *Corresponding author E-mail:norlaile@fpe.upsi.edu.my
}

\begin{abstract}
The conventional lecture teaching style designed by our education system is becoming less relevant in meeting the millennial students' learning necessities. Common lecture seems no longer adequate in developing an engaging and effective lesson for the graduates. For that reason, Malaysian Ministry of Education suggests SERVICE-LEARNING (SL) to be conducted to supplement student learning. Nevertheless, prior studies on SL effectiveness showed mixed results. Therefore, this study is conducted to understand and provide a detailed account of students' learning development in a higher education institution in Malaysia. By employing the qualitative methodology, 39 students participated in SL project were interviewed to understand students' learning development. The responses were transcribed verbatim and analyzed by using thematic analysis. The results revealed that knowledge and skills developed meaningfully through SL unlike in typical classroom setting where knowledge is expected to flow effectively from lecturers to students without real world experience or lasting impact. However, some students were found to understand the lesson slightly different from their peers. This research provides guidelines for course instructors to design SL in academic courses and improve student learning for the purpose of realizing Malaysian Education Blueprint 2013-2025.
\end{abstract}

Keywords: Service learning; higher education; learning development

\section{Introduction}

Higher learning institutions have been challenged to increase the employability of their graduates by providing the right technical skills, soft skills and work ethics (1). In line with that statement, majority of employers suggested that the curriculum in higher learning institutions must be enhanced to equip and create industry preferred and relevant graduates (2). As a matter of fact, Malaysian government has realized about this rising issue even earlier. Therefore, in 2006, the Ministry of Higher Education (MoHE) has identified seven soft skills that should be possessed by all graduates as indicated in the Module for the Development of Soft Skills for Higher Learning Institution Malaysia which include the following skills: i. critical thinking and problem solving skills, ii. communication skills, iii. lifelong learning and information literacy, iv. team-working skills, v. professional ethics and morality, vi. entrepreneurship skills, and vii. leadership skills (3). These skills particularly communication skills, integrity and professional ethics, and teamwork were proven to be demanded by industry (4). Besides soft skills, hard skills were equally important dimensions of graduate employability from the perspectives of employers (5). In the context of business students, several important skills have been identified as depicted in Table 1.

Despite the aim to equip the graduates with adequate knowledge and skills, the majority of Malaysian lecturers and teachers are still practicing the conventional learning method where the educators serves as the repository of knowledge (6). For instance, a survey among Malaysian students in a university showed that majority of the lecturers used personal model where they tend to direct and guide the students to observe and imitate the method shown after that (7). Even in schools, most Malaysian teachers preferred to practice personal model of teaching styles (8). In a sample which comprised of Malaysian lecturers and teachers, only 10 percent of them preferred delegator teaching style which develop students' ability to function autonomously (9). Further evidence showed that didactic teaching styles was also common in Malaysian higher education institution (10). Didactic teaching style is a teacher centered approach where the teachers play the role as the main source of knowledge transmitter. On the whole, teachers and lecturers rather than students being the central to teaching in learning are still a common practice in Malaysia.

Table 1: Non-technical skills required in business graduates

\begin{tabular}{|l|l|}
\hline Skill & Behavior \\
\hline Core business skills & Numeracy, technology \\
\hline Critical thinking & Pattern recognition and conceptualization; evaluation \\
\hline Problem solving & Analytical/convergent reasoning; diagnosing \\
\hline Decision management & Lateral thinking/creativity; information management; decision making \\
\hline Political skills & Influencing others; conflict resolution \\
\hline Working with others & Task collaboration; team working; social intelligence; cultural and diversity management \\
\hline Oral communication & Verbal communication; giving and receiving feedback \\
\hline Personal ethics & Personal ethics \\
\hline \hline
\end{tabular}

Copyright $\odot 2018$ Authors. This is an open access article distributed under the Creative Commons Attribution License, which permits unrestricted use, distribution, and reproduction in any medium, provided the original work is properly cited. 


\begin{tabular}{|l|l|}
\hline Confidence & Self-efficacy \\
\hline Self-awareness & Meta-cognition; lifelong learning \\
\hline Self-discipline & Self-regulation; stress tolerance; work/life balance \\
\hline Innovation & Entrepreneurship; change management \\
\hline Leadership & Project management; performance management; meeting management; developing others \\
\hline Formal communication skills & Public speaking; meeting participation; written communication \\
\hline Performance & Efficiency; multi-tasking; autonomy \\
\hline Organizational skills & Goal and task management; time management \\
\hline Environmental awareness & Organizational awareness; commercial awareness \\
\hline Professional responsibility & Social responsibility; accountability \\
\hline Work ethics & Drive; initiative \\
\hline
\end{tabular}

Source: (11)

Despite the aim to equip the graduates with adequate knowledge and skills, the majority of Malaysian lecturers and teachers are still practicing the conventional learning method where the educators serves as the repository of knowledge (6). For instance, a survey among Malaysian students in a university showed that majority of the lecturers used personal model where they tend to direct and guide the students to observe and imitate the method shown after that (7). Even in schools, most Malaysian teachers preferred to practice personal model of teaching styles (8). In a sample which comprised of Malaysian lecturers and teachers, only 10 percent of them preferred delegator teaching style which develop students' ability to function autonomously (9). Further evidence showed that didactic teaching styles was also common in Malaysian higher education institution (10). Didactic teaching style is a teacher centered approach where the teachers play the role as the main source of knowledge transmitter. On the whole, teachers and lecturers rather than students being the central to teaching in learning are still a common practice in Malaysia.

Lecturers and teachers in Malaysia choose to become the center of learning for a number of reasons which among others due to the students' characteristics. Students in Malaysia seems to require more direction and closer supervision from the lecturers (12). Without careful guidance, it is afraid that students may not be able to achieve the learning objectives and complete tasks given. Nevertheless, excessive guidance and direction may limit the skills that a student can develop throughout the learning process, and eventually it will not help the students improve their employability. This indicates that part of the employability problem is irrefutably due to ineffective delivery system in higher education institutions (13). As a result, Malaysian students were perceived as inadequate in terms of knowledge and skills when they enter the labor market. For example, responses from lecturers and employers revealed that students cannot recall what they learned in the past, thus lead to unemployment problem (14). The problem does not stop there, but continues to their early employment time. When these students were hired, employers reported that students faced some difficulties in understanding the new environment surrounding them (15). Meanwhile, respondents from the factory and commerce rated the lowest satisfaction score for students' hands-on skills (15). In addition, students demonstrated the lack of technical knowledge and facing the difficulty in applying knowledge to solve work tasks (16). Overall, the previous findings imply that the traditional teaching strategies are not sufficiently effective in developing knowledge, skills and values among the students especially in suiting to the changing learning styles of students in this generation.

Due to ineffectiveness of education delivery system, graduates in Malaysia are feared to no longer able to compete in the era of the Industrial Revolution 4.0 since they are not capable of applying the theories learned in higher education institutions, utilizing the skills and practicing good values in carrying out their works. Considering that work environments will be going through a period of tectonic shifts where flexible working arrangement such as remote working and teleconferencing are more common particularly due to the development of internet and technology (17), employees are more likely to be working from other countries with only small pool of core full-time employees located in a physical office. Thus, employees will have to work independently and carry out their responsibility without constant supervision and instruction from the employers. These new working conditions demand the graduates to embrace the top four skills which are cognitive abilities, system skills, complex problem solving and content skills (17). System skills refer to judgment and decision making skills, while content skills refer to active learning, oral expression, reading comprehension, written expression and ICT literacy. When comparison is made, these skills set happens to concur with the seven skills in the Module for the Development of Soft Skills for Higher Learning Institution Malaysia identified earlier in 2006 (3).

To ensure that appropriate knowledge and skills are effectively developed among students, Service-Learning (SL) was introduced by the Ministry of Education and attempts to implement SL in a structured manner have been made in several universities in Malaysia. For example, community service co-curricular was established in Universiti Tun Hussein Onn Malaysia (18) whereas, in Universiti Teknologi Malaysia, UTM courses and community service were commenced since 2011/2012 to instil ethics and professionalism while providing students with the opportunity to translate technical knowledge into practice (19). For other universities, SL is embedded in individual courses as part of their project assignments.

SL has been claimed to offer better solution to poor graduate skills and knowledge development problem. Students were able to receive new knowledge and skills, develop their potential, challenge themselves in the process of solving problems, and apply the values and develop soft skills for their career benefits through SL (19). However, there were also earlier researchers who found mixed evidence of SL effectiveness (20-23). Therefore, this research is conducted to understand and provide a detailed account of the learning development in a higher education institution. The findings of this research helps educators understand about the implementation of SL and weigh the pros and cons of this teaching strategy.

\section{Literature Review}

\subsection{Service-Learning (SL)}

SL has been used interchangeability with community service, volunteerism, community-based learning, civic engagement and service-learning internship (24). SL fits into several learning theories such as the Lewin's iterative model of action learning and constructivist learning theory which explains that learning process starts with a prior knowledge and reconstructed through reflective piece that impact future actions (22). SL is also known as an experiential learning strategy which applies Kolb's experiential learning cycle as depicted in Figure 1 (25). The experiential learning cycle is created by the recursive flux of concrete experience, reflective observation, abstract conceptualization, and active experimentation. Concrete experiences develop the basis for observations and reflections where these reflections are integrated and extracted into abstract concepts. These abstract concepts then can be actively tested by the learners through experimentation and thus create new experiences for them. 


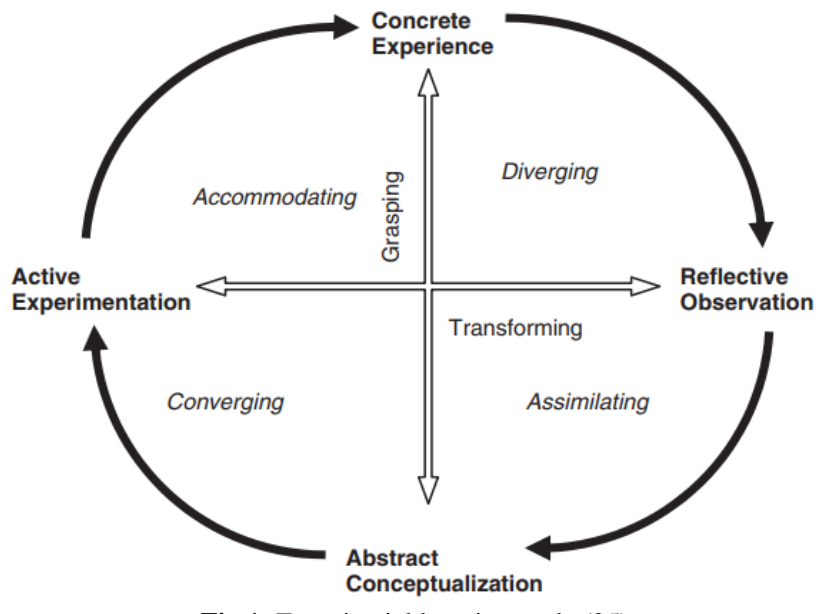

Fig.1: Experiential learning cycle (25).

Although SL has been used interchangeably with volunteerism, community service, field education and internship, the main difference between SL and other service programs can be identified based on the beneficiary and focus of those programs. Unlike volunteerism and internship where the main beneficiaries are the service receivers and learners respectively, SL creates a symbiotic relationship between service receiver and learners. Figure 2 exhibits the differences between SL and other service programs.

Previous studies reported mixed evidence regarding the effectiveness of SL. In a research consisting multiple SL projects, one of the SL projects was less successful in delivering the desired lesson (22). In consistence, in an ethics course, it was found that students' moral reasoning was not different between those who took traditional ethics course and SL (20). This study also discovered that students who participate in SL did not use ethical philosophy in resolving ethical dilemmas more frequently than others who took traditional ethics course. Nevertheless, a number of other researchers claimed successful SL. It was reported that SL can truly link theory and practice $(21,26)$ and that students' learning experience in terms of knowledge, attitude and skills were increased (23). Considering these mixed evidences, what actually have influenced the effectiveness of SL?

SL was less successful because of students' motivation (22). Without enough motivation, students did not care to learn how to integrate theory and practice. They merely involved in the SL project for the sake of completing the course, and maybe to learn few theories and hoped that they could passively analyse corporate case studies in a classroom setting (22). As a result, such students may involve in an SL project but were not be able to capture the essence of the learning and improve their knowledge or skills accordingly. In alignment, rather than randomly assign students with varying background of servicing experience to SL or non-SL section of the courses, students self-selected to join the SL project which might be influenced by their own motivations (20).

Besides, the age also plays an important role because older students are more matured and have different cognitive level than younger students. SL project which was less successful (20) had students whose mean age were 18.5 years old whereas SL project which was more successful (26) had students aged between 20 24 years old. Pertaining to the positive results from the study performed by (26), it is crucial to note that the SL project was conducted at an international level and participated by various organizations. For such a huge project which consumed substantial costs, it is hard to negate that at least average students, if not the best, were selected to represent the university especially when the students were required to demonstrate high problem solving skill and vast knowledge in to complete the required tasks. In summary, it implies that the characteristics of the students also influence the outcome of SL. Therefore, in the era of Education 4.0, the profiles of Malaysian millennial students seemed to be worth examined to gain better understanding of SL.

\subsection{Characteristics of Millennial Students}

Millennials or sometimes called Generation $\mathrm{Y}$ and $\mathrm{Z}$ are people born between 1980 and 2000 (27). Born in the era of internet and digitalization, prominent characteristics of earlier generations are no longer visible in the Millennial. Compared with previous generations, Millennial have greater needs to belong to certain social groups and to share with others (28).

Besides the need to belong to a social group, sharing with others and demand for instant recognition, the Millennial demonstrate stronger team instincts and tighter peer relationships, and greater needs to achieve and succeed $(28,29)$. In parallel, they seem to favor group activities (30) because they strongly believed that collaboration is superior to individual efforts (31). Doing things together develops higher team spirit and results in greater impact on the better society and social aspects of learning $(30,32)$. It was further claimed that Millennial students showed an interest in engaging in civic activities such as voting, charity, and community service compared to students from earlier generations (33).

According to a research, the Millennials' cognitive thinking and physical well-being are suffering because too much of their time are spent in sedentary for example by watching televisions, movies, video, games and playing computers (34). Spending too much time on the internet also caused them to have the difficulties in socializing with people (35). Other studies further explained that the Millennials are multitaskers, ethnically diverse and digitally literate who prefer experiential and engaging learning environment and demand immediate access and responses (36). Despite being digitally literate, Millenials may be easily distracted on the Internet and may have difficulties in sustaining their concentration over long periods of time (35). In addition, the Millennial are kinesthetic and visual learners, and they read less and less well (37). In Malaysian context, the millennial students prefer to do tasks in group, expect round-the-clock mentoring from their incumbents, and unmotivated (38).

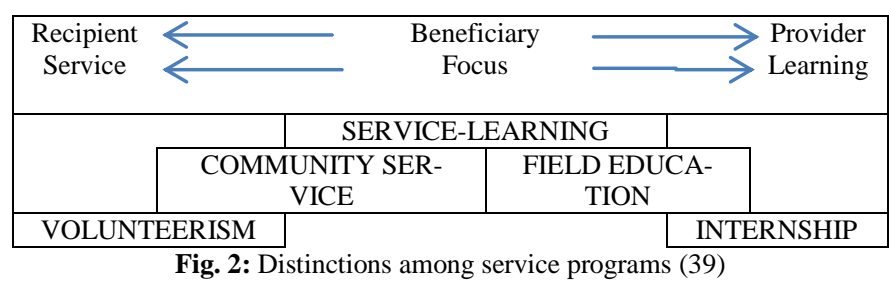

These characteristics were nurtured by the "helicopter parents" since their early childhood (40). Helicopter parents is a term coined by Dr. Haim Ginott in 1969 which refers to parents who are over protective and so afraid that their children will get hurt. They always hover over their children so that they can rescue them immediately if possible. The helicopter parents brought up their children as "trophy kids", a term given to indicate children who receives constant and pouring praise along with minimal punishment, which most of the times develop children who believes that they are special, talented, unique and above-average (41).

Based on the characteristics of the Millennials discussed above, obviously there is a mismatch between the profiles of Millennial students and the knowledge and skills needed for the future jobs. Even worse, the traditional course design whereby students spend a lot of time attending lecture-style class and reading is no longer adequate to feed the learning necessities and develop necessary skills for the Millennials. Thus, educational styles must be adapted in order to effectively educate the Generation Y (37). For that reason, SL seems to be a relevant solution to complement the lacking in the conventional teaching style. However, evidence on SL's effectiveness is inconclusive and there is still limited evidence about SL implementation especially in Malaysian context. Thus, a detail description on how SL was adopted in academic courses 
should be explored to understand the students' learning development of this strategy.

\section{Methodology}

"An evaluation aimed at assessing whether an intervention is effective might call for a quantitative study; however, an evaluation aimed at assessing the nature of the intervention and its implementation might call for a qualitative study" (42). By referring this intervention to SL, therefore, this study employed qualitative methodology. In order to understand the students' learning development, an interview protocol adapted from (43) were developed and students enrolled for SL projects were interviewed. The interview protocol, therefore, contained three sections which were constructed based on DEAL (Describe, Examine, and Articulate Learning) model. In the "Describe" section, the study participants were asked to elaborate on their SL experiences in terms of their roles, selection of the SL organization and prior experiences in such project. Meanwhile, in the "Examine" section, study participants explained in detail about their learning development by following the sequence of Bloom's Taxonomy. Finally, study participants were asked to describe the extent to which the SL project affected them in the future in the "Articulate Learning" section. Altogether, 8 focus group interviews were conducted which comprised of 39 students participated in a SL project. The interview data were transcribed verbatim and analyzed by using thematic analysis in order to identify the themes. The thematic analysis was performed according to the suggestion made by LeCompte (44). The data analysis was carried out according to five steps which are i. tidying up data, ii. finding items and unit of analysis, iii. creating stable sets of items, iv. creating patterns, and v. assembling structure. The findings of this study were verified by member check and triangulation of data.

\section{Results and Discussion}

39 students of Social Entrepreneurship course aged 19-20 years old were assigned randomly into two groups. Since all the students were from their final year of Diploma in Entrepreneurship program, the SL projects were designed so that the students would be able to apply the knowledge that they learned in previous semesters such as marketing, ethical principles, management, and also the new concepts of Social Entrepreneurship in their current semester to carry out the SL project successfully. Each group of students then formed an organization like structure where they appointed a director of the program, the deputy director, the treasurer, and heads of committee to complete the first phase which was to select the organizations they were going to serve. At this point, real work environment problem such as budget and time limitation were purposely introduced to imitate the actual working conditions where managers had to consistently deal with. In addition, students were supposed to link the four major functions of a manager in the Principles of Management course namely plan lead, organize and control in the structure they developed. Moreover, they were expected to apply the ethical principles they learned during their first year for example the utilitarianism, Kant's categorical imperative and ethics of care to justify the decision they made about the selection of SL organizations.

Three options were considered; two children homes and a poor family who had a bedridden husband and small children. Finally, two organizations were finally selected. Pertubuhan Anak-anak Yatim dan Miskin, Sabak Bernam and Rumah Anak-anak Yatim Sekendi were organizations serving children from underprivileged families and orphanages in Selangor, Malaysia. Both organizations were the homes for $15-25$ children who were still studying in the primary and secondary schools. Unlike other children homes in Malaysia, these two organizations did not have consistent contribution or donation of food, school supplies, money and volunteer time for their survival. They depended solely on any donation and contribution from companies and nearby society. Recently, the Head of Rumah Anak-anak Yatim Sekendi who the children acknowledged as their own father passed away. At the time when this SL project was conducted, the children were still awaiting for a new replacement. In this phase, however, only the director, deputy director, treasurer and the heads of the committee seemed to be highly involved in decision making whereas other students merely attended meetings and listened passively. Despite that, they also were not able to link their decisions according to the ethical principles they learned. They chose the two organizations based on the limitations of this project and what they think was right.

The goal of the SL projects at both organizations was to raise decent contributions to start the new schooling year for the children. Based on the conversation with the representatives of the organizations, they needed daily necessities such as stationeries and school supplies apart from food and toiletries. In order to achieve the goal, all 39 students were introduced to the second phase of the SL project which was fundraising. The fundraising phase required the students to set up their own business and allocate some amount from the profit as a donation to the children homes. Students were encouraged to apply their entrepreneurial skills such as creativity and innovation skills in raising the funds. At the beginning of this 10-week phase, majority of students formed groups comprised of 2-3 students to run food, car rental, massage therapy businesses and etc. Many of these students never had an experience in actually running a business or even working in a company. Due to that, many of them encountered customers' rejection, profit loss and other problems related with business regulations which developed a concrete experience for them as in the experiential learning cycle (25).

This intense experience led them to make reflections about their own selves in terms of knowledge and skills, and their business strategies for example how to identify profitable market and what kind of products would serve the target market which was in line with the second stage in experiential learning cycle (25). As a result, in the middle of the fundraising phase, the students experiment their new abstract conception (25) by restructuring their businesses. For instance, one male student who was clearly showing good business performance grew his business by increasing the number of his group members (similar with employees) in his business. He persuaded his friends who did not seem to be performing very well during the early phase to collaborate with him. In the new group, he demonstrated craftsman leadership where he always listened to suggestion from his friends about product innovation and marketing plan before making any decisions. Nevertheless, several students continued to raise fund alone. Another male student also started negotiating with a company for corporate funding. At the end of the second phase, both groups raised around RM2,000 (approximately USD504) for donations although some students were able to contribute much larger amount than others as a results of their active experimentation on how to raise the fund. The outcomes from the experiments eventually created a new concrete experience for them, thus completed the experiential learning cycle (25).

The third phase of the SL project required the students to go to the children homes and carry out a one-day activity besides giving away the donations. This phase provided them with the opportunity to actually meet the beneficiary of their hard works. As early as 7.00 a.m. they took an hour bus trip to the children homes. For the first group, the activity started with an ice-breaking sessions between the students and the children and followed by several sessions where the students taught the children on how to make simple handicrafts, massage techniques, and creative problem solving skills to instill entrepreneurial spirits and minds. Concurrently, some of the students cleaned up the small mosques and helped preparing lunches for everyone. Meanwhile, for the second group, they played some games with the children and initiate motivational conversation where the children poured their hearts out. The 
third phase was expected to develop entrepreneurial characteristics such as empathy, passion, motivation and strong people skill. A week after that, the students came to the final phase where they were given the chance to reflect on their overall learning experiences through class presentation.

The students admitted that the SL project helped them to understand about the lesson effectively because it enabled him to link between theory and practice which agree with earlier researchers $(21,26)$.

"When I involved in that project, I think I can memorize (the lesson). It's easier to remember...for example, If we're going to sit for an examination, we'll read and memorize all the lessons. So, while we're memorizing, we're actually trying to link (the lessons) with what we've gone through. It's easier to understand the lesson through our own experience."

"When I was studying (for final examination), I tried to relate the lessons with the project. I had to relate it with my life."

Apart from cognitive development, the SL projects successfully prepared the students behaviorally and affectively towards becoming a better entrepreneur and citizen. This is proven by the following excerpt.

"In general, we enjoyed doing that project. But when we look closely from the original scope, we should do more. Things need to be upgraded. In future, we can't just help them but the objective should be a long-termed one. Not just raising money to feed the children. It can't be just that. We should think of something that has long-termed benefits."

Based on the findings, students had enjoyed learning through SL pedagogy which is similar to the finding in past research (45). Students enhanced their knowledge and reinforced skills they acquired, developed their potential, continuously challenged themselves through countless obstacles and embraced the values they meant to understand (19). In addition, the finding of this study contested prior study who claimed that SL was less successful for younger students aged 18.5 years old (20). More importantly, data from this research revealed that knowledge and skills developed meaningfully through SL unlike in typical classroom setting where knowledge is expected to flow effectively from lecturers to students without real world experience or lasting impact.

\section{Conclusion}

This research was conducted to understand students' learning development through SL projects. 39 students participated in SL projects were interviewed and observed throughout a semester. This research found evidences that support the effectiveness of SL pedagogy in terms of cognitive development as participants demonstrated the ability to link theories and practice. In addition, the SL projects provide transformative experience towards students' behavioral and affective aspects when they showed the readiness to become a better entrepreneur and citizen for the society. However, there is a lesson worth considering for educators who plan to employ this teaching pedagogy. The SL project needs to be carefully tailored according to students' characteristics, so that expected lesson will be learned by the students. For future research, more studies should be conducted on how SL can be designed so that targeted lesson can occur among students.

\section{Acknowledgement}

This research is funded by Universiti Pendidikan Sultan Idris Research Grant (2017-0168-106-01).

\section{References}

[1] Lee MNN. Educational reforms in Malaysia: Towards equity, quality and efficiency: Taylor \& Francis; 2014.

[2] Seetha N. Are Soft skills Important in the Workplace?-A Preliminary Investigation in Malaysia. International Journal of Academic Research in Business and Social Sciences. 2014;4(4):44.

[3] Mohd Adnan Y, Daud MN, Alias A, Razali MN. Importance of Soft Skills for Graduates in the Real Estate Programmes in Malaysia. Journal of Surveying, Construction and Property. 2017 2017-08-23;3(2)

[4] Singh P, Thambusamy RX, Ramly MA. Fit or unfit? Perspectives of employers and university instructors of graduates' generic skills. Procedia-Social and Behavioral Sciences. 2014;123:315-24.

[5] Ghazali G, Bennett D. Employability for music graduates: Malaysian educational reform and the focus on generic skills. International Journal of Music Education. 2017;35(4):588-600.

[6] Yusof Yusmarwati, Roddin Rohayu, Awang Halizah. What Students Need, and What Teacher Did: The Impact of Teacher's Teaching Approaches to the Development of Students' Generic Competences. Procedia - Social and Behavioral Sciences. 2015 2015/08/24/;204:36-44

[7] Shaari AS, Yusoff NM, Ghazali IM, Osman RH, Dzahir NFM. The relationship between lecturers' teaching style and students' academic engagement. Procedia-Social and Behavioral Sciences. 2014;118:10-20.

[8] Yusof H, Vyapuri L, Jalil NA, Mansor M, Noor MAM. The Factors Affecting Teacher Leadership in Malaysian Primary Schools. International Journal of Academic Research in Business and Social Sciences. 2017;7(6):620-31.

[9] Ph'ng LM, editor. Teaching Styles, Learning Styles and the ESP Classroom. MATEC Web of Conferences; 2018: EDP Sciences.

[10] Annafatmawaty B.T. Ismail, Sukanlaya S, Roxanne Z. Entrepreneurship education pedagogy: teacher-student-centred paradox. Education + Training. 2018;60(2):168-84.

[11] Jackson D. Business graduate employability-where are we going wrong? Higher Education Research \& Development. 2013;32(5):776-90.

[12] Siddiqui MH. Technology in Higher Education: APH Publishing Corporation; 2004.

[13] Grapragasem S, Krishnan A, Mansor AN. Current trends in Malaysian higher education and the effect on education policy and practice: An overview. International Journal of Higher Education. 2014;3(1):85.

[14] Hanapi Z, Nordin MS. Unemployment among Malaysia graduates: Graduates' attributes, lecturers' competency and quality of education. Procedia-Social and Behavioral Sciences. 2014;112:1056-63.

[15] Chiu LK, Mahat NI, Rashid B, Razak NA, Omar H. Assessing Students' Knowledge and Soft Skills Competency in the Industrial Training Programme: The Employers' Perspective. Review of European Studies. 2016;8(1):123

[16] Lim Y-M, Lee TH, Yap CS, Ling CC. Employability skills, personal qualities, and early employment problems of entry-level auditors: Perspectives from employers, lecturers, auditors, and students. Journal of Education for Business. 2016;91(4):185-92.

[17] World Economic Forum. The future of jobs: employment, skills and workforce strategy for the fourth industrial revolution. Geneva: World Economic Forum; 2016.

[18] Jalil A, Azyani N, Esa A. Kemahiran menyelesaikan masalah menerusi aktiviti kokurikulum (khidmat masyarakat) dalam kalangan pelajar. 2012.

[19] Salleh MSM, Mokhtar M. Service Learning: Experiences and Perceptions Towards Students in UTM, Malaysia. Sains Humanika. 2017;9(1-3).

[20] Bernacki ML, Jaeger E. Exploring the impact of service-learning on moral development and moral orientation. Michigan Journal of Community Service Learning. 2008;14(2).

[21] Flannery BL, Pragman CH. Service-learning and integrated course redesign: Principles of management and the campus kitchen metaproject. Journal of Management Education. 2010;34(1):11-38.

[22] Vega G. Teaching business ethics through service learning metaprojects. Journal of Management Education. 2007;31(5):64778.

[23] Schoenherr T. Service-Learning in Supply Chain Management: Benefits, Challenges and Best Practices. Decision Sciences Journal of Innovative Education. 2015;13(1):45-70. 
[24] Stelljes AD. Service-learning and Community Engagement: Cognitive Developmental Long-term Social Concern: Cambria Press; 2008.

[25] Kolb AY, Kolb DA. Experiential learning theory: A dynamic, holistic approach to management learning, education and development. The SAGE handbook of management learning, education and development. 2009:42-68.

[26] Ghee WY, Zakaria F. Promoting civic engagement through a service learning experience. International Journal of Humanities and Social Science. 2012;2(12):83-8

[27] Weber J, Urick MJ. Examining the Millennials' Ethical Profile: Assessing Demographic Variations in Their Personal Value Orientations. Business and Society Review. 2017;122(4):469-506.

[28] Lancaster LC, Stillman D. When generations collide. New York: Harper Collins Publishers Inc.; 2002

[29] Howe N, Strauss W. Millennials rising: The next great generation: Vintage; 2009.

[30] D'Souza MJ, Rodrigues P. Engaging Millennial Students in an Engineering Classroom using Extreme pedagogy. Indian Journal of Science and Technology. 2015;8(24):1.

[31] Pinder-Grover T, Groscurth CR. Principles for teaching the millennial generation: Innovative practices of UM faculty. Center for Research on Learning and Teaching. 2009;26:1-8.

[32] Tewari S, Bhattacharyya R, editors. Aspirations \& Wants of Generation Z-A Study on the Work Force of the Future. International Conference on Technology and Business Management April; 2017.

[33] Gloeckler G. Here come the millennials. Business Week. 2008;4109:46-50.

[34] Weiler A. Information-seeking behavior in generation Y students: Motivation, critical thinking, and learning theory. The journal of academic librarianship. 2005;31(1):46-53.

[35] Karakas F, Manisaligil A, Sarigollu E. Management learning at the speed of life: Designing reflective, creative, and collaborative spaces for millenials. The International Journal of Management Education. 2015;13(3):237-48.

[36] Phillips CR, Trainor JE. Millennial students and the flipped classroom. Journal of Business and Educational Leadership. 2014;5(1):102.

[37] Reilly P, editor. Understanding and Teaching Generation Y English teaching forum; 2012: ERIC.

[38] Raslie H, Pit S, Ting S-H. Millennials' Expectations of Life at the University and the Workplace: A Malaysian Perspective. International Journal of Education. 2016;8(3):71.

[39] Furco A. Service-learning: A balanced approach to experiential education. 1996

[40] McAllum K. Instructional Communication and Millennial Students: Managing Imposter Syndrome among the" Trophy Kids": Creating Teaching Practices That Develop Independence in Millennial Students. Communication Education. 2016;65(3):363-5.

[41] Twenge JM, Campbell WK, Gentile B. Generational increases in agentic self-evaluations among American college students, 19662009. Self and Identity. 2012;11(4):409-27.

[42] Yin RK. Qualitative research from start to finish: Guilford Publications; 2015.

[43] Bringle RG, Ruiz AI, Brown MA, Reeb RN. Enhancing the Psychology Curriculum Through Service Learning. Psychology Learning \& Teaching. 2016;15(3):294-309.

[44] LeCompte MD. Analyzing Qualitative Data. Theory Into Practice. 2000;39(3):146-54.

[45] Mat-jizat JE, Khalid K. A Service-Learning Project Using Crowdfunding Strategy: Students' Experience and Reflection. International Association for Development of the Information Society. 2016. 